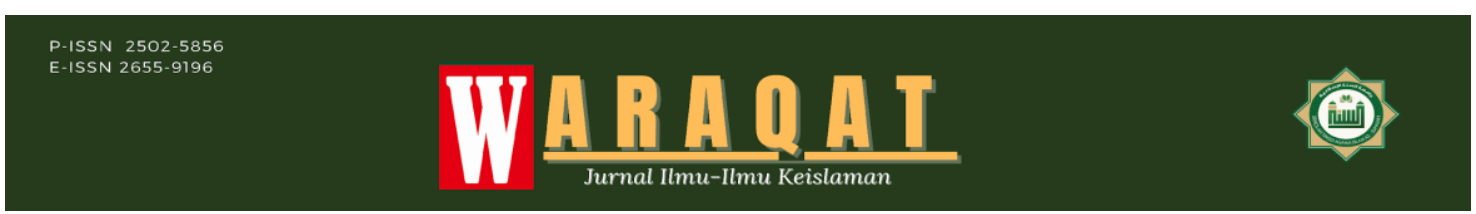

\title{
Implementasi Manajemen Pembelajaran Daring Pada Masa Pandemi di SMP Negeri 7 Sijunjung
}

\author{
Rika Wahyuni ${ }^{1}$, Suswati Hendriani ${ }^{2}$, Devy Aisyah ${ }^{3}$ \\ ${ }^{1 .}$ Institut Agama Islam Negeri Batusangkar \\ 2. Institut Agama Islam Negeri Batusangkar \\ 3. Institut Agama Islam Negeri Batusangkar \\ rikawahyuni12684@gmail.com
}

\begin{abstract}
The sudden spread of the covid-19 virus has resulted in social changes that have caused stuttering in the process of adjusting learning activities. That's why online learning must be done in order to achieve ideal learning at SMP Negeri 7 Sijunjung. This study aims to describe the planning, implementation and evaluation or control of during learning the covid 19 pandemic at SMP Negeri 7 Sijunjung. The results showed that, 1). The planning stage is carried out through several stages, namely the first small meeting of the Headmaster, Deputy of Headmaster for Curriculum sector and the Chief of Administration, the results of the small meeting are brought to the teachers council meeting, then the results of the meeting are socialized to parents and students 2). The implementation of daring learning the Covid 19 pandemic at SMP Negeri 7 Sijunjung was carried out by the Headmaster to each field teacher, namely by using the Whatsapp Group Mapel, Google Classrom and Google Form to send material, whether in the form of photos, videos or LKPD 3). Evaluation of daring learning the covid 19 pandemic at SMP Negeri 7 Sijunjung was carried out by the Headmaster along with the Deputy of Headmaster for Curriculum sector by controlling directly into the class and subject groups of each teacher and conducting monthly briefings related to daring learning.
\end{abstract}

Keywords: Daring Learning Management; Journal Covid 19 Pandemic

\begin{abstract}
Abstrak
Ini adalah Merebaknya penyebaran virus Covid-19 yang secara tiba-tiba mengakibatkan perubahan sosial yang telah menimbulkan kegagapan dalam proses penyesuaian kegiatan pembelajaran. Karena itulah pembelajaran daring harus dilakukan demi mencapai pembelajaran yang ideal di SMP Negeri 7 Sijunjung. Hasil penelitian menunjukkan bahwa, 1). Tahap Perencanaan dilakukan melalui beberapa tahapan yaitu pertama rapat kecil Kepala Sekolah, Wakil Kurikulum dan KTU, hasil dari rapat kecil tersebut dibawa ke dalam rapat majelis guru, kemudian hasil dari rapat disosialisasikan kepada orang tua dan siswa 2). Pelaksanaan pembelajaran daring pada masa pandemic covid 19 di SMP Negeri 7 Sijunjung diserahkan pelaksanaannya oleh kepala sekolah kepada masing-masing guru bidang studi yaitu dengan menggunakan Whatsapp group Mapel, Google Classrom dan Google Form untuk mengirimkan materi, baik itu berupa foto, video, atau LKPD 3). Evaluasi pembelajaran daring pada masa pandemi covid 19 di SMP Negeri 7 Sijunjung dilakukan oleh Kepala Sekolah bersama dengan Wakil Kepala Bidang Kurikulum dengan melakukan pengontrolan langsung kedalam group kelas dan mapel masing-masing guru dan melakukan briefing setiap bulan terkait dengan pembelajaran daring.
\end{abstract}

Kata Kunci: Manajemen Pembelajaran Daring; Pandemi Covid 19

Article Info

Article History:

Recived: 07/11/2021. Accepted: 11/12/2021. Publish: 16/12/2021 


\section{Pendahuluan}

Guru diharapkan mampu mengelola pembelajarannya secara efektif. Guru memegang peranan penting dalam mengontrol pembelajaran. Karena guru adalah pelaksana proses belajar mengajar, maka keberhasilan pelajaran menentukan keberhasilan pendidikan umum. Studi teoritis telah menunjukkan bahwa jika guru dapat menggunakan fasilitas pembelajaran untuk melakukan pekerjaannya sebagai guru dalam merancang situasi pembelajaran, mereka dapat secara efektif dan efisien mengelola pembelajaran dalam tugas-tugas fungsional mereka. Proses. (Buchari, 2018: 106).

Kemampuan manajemen diperlukan untuk mencapai tujuan ini. Fungsi manajemen terdiri dari apa yang dilakukan dalam urusan manajemen. Fungsi manajemen dikonfigurasi untuk mencapai perspektif umum untuk mencapai tujuan yang ditetapkan. Manajemen adalah proses perencanaan, pengorganisasian, pengarahan, dan pengendalian kegiatan anggota organisasi, menggunakan sumber daya organisasi lain untuk mencapai tujuan organisasi tertentu. Kemampuan manajemen diharapkan dapat mencapai tujuan tersebut. Dari berbagai fungsi manajemen yang dikemukakan oleh para ahli, dapat disimpulkan bahwa fungsi utama manajemen terdiri dari tiga fungsi utama yaitu perencanaan (planning), pengorganisasian (organization), dan pengendalian (monitoring).

Rencana harus ada dalam setiap kegiatan, yang sesuai dengan konsep manajemen. Allah menegaskan dalam al-Qur'an pada surat Al-Hasr ayat 18, yang berbunyi:

"Hai orang-orang yang beriman, bertakwalah kepada Allah dan hendaklah Setiap diri memperhatikan apa yang telah diperbuatnya untuk hari esok (akbirat); dan bertakwalah kepada Allah, Sesunggubnya Allah Maha mengetahui apa yang kamu kerjakan”. (QS. Al-Hasr: 18).

Menurut Muhammad Ali al-Shabuni dalam mengartikan lafadz "wa al-tandzur nafsun maa qaddamat lighot" adalah hendaknya masing-masing individu untuk memperhatikan amalamal saleh apa yang diperbuat untuk menghadapi hari kiamat (Al-Shabuni, 2001: 355). Dalam tafsir Al-Maraghi penjelasan lafadz "Ma qaddamat yaitu apa yang telah dilakukan,"Ghad" yaitu hari kiamat, dinamakan ghad (besok hari) karena dekatnya, sebab segala yang akan datang (terjadi) adalah dekat sebagaimana dikatakan sesungguhnya besok hari itu bagi orang yang menanti adalah dekat. Pengertian secara ijmal yaitu orang-orang mukmin agar tetap bertaqwa dan mengerjakan di dunia yang bermanfaat di akhirat, sehingga mereka mendapatkan pahala besar dan kenikmatan yang abadi (Al-Maraghi, 1989: 86-87). Menurut Mujamil Qomar bahwa, ayat ini memberikan pesan kepada orang-orang yang beriman untuk memikirkan masa depan. Dalam dunia manajemen, pemikiran masa depan yang dituangkan dalam konsep yang jelas dan sistematis disebut dengan istilah perencanaan atau planning (Qomar, 2007: 30).

Manajemen pembelajaran institusional harus mencakup prinsip-prinsip yang perlu bertindak sebagai pedoman baik dalam proses desain dan implementasi. Prinsip perencanaan "pendidikan itu efisien, efisien, dan fleksibel". Perencanaan merupakan bagian dari fungsi manajemen. Manajemen selalu terdiri dari tiga elemen penting. Artinya, (a) upaya bersama, (b) dua orang atau lebih, dan (c) pencapaian tujuan yang telah ditetapkan. Dalam pengertian ini telah ditunjukkan adanya gerakan-gerakan untuk mencapai tujuan yang telah ditetapkan: usaha bersama, personel yang melaksanakannya, yaitu dua orang atau lebih, dan gerakan-gerakan di mana kegiatan-kegiatan tersebut dilakukan. Ketiga faktor tersebut, pergerakan, orang, dan arah kegiatan, menunjukkan bahwa manajemen dilakukan 
di dalam organisasi dan bukan merupakan tugas tunggal yang dilakukan oleh suatu institusi seperti individu atau sekolah.

Wabah pandemi Corona Virus Disease 2019 (Covid19) sejak Desember 2019 hingga saat ini berdampak besar pada proses pembelajaran di sekolah. Akibatnya, seluruh proses pembelajaran di sekolah harus dilakukan di rumah. Hal ini dilakukan untuk meminimalisir kemungkinan kontak fisik yang bertujuan untuk memutus mata rantai penyebaran virus tersebut. Pemerintah telah mengeluarkan kebijakan bahwa proses pembelajaran harus dilakukan secara online atau offline baik menggunakan ponsel, laptop, atau PC untuk menyelesaikan proses pembelajaran yang harus diselesaikan tahun ini. .. Sistem online diharapkan mampu merepresentasikan dunia pendidikan dalam rangka melanjutkan pendidikan dan memutus mata rantai penyebaran Covid-19.

Menurut jurnal yang ditulis Dian Herdiana dan Supriatna Nurul, tatanan normal baru merupakan kebijakan pemerintah untuk menjaga aktivitas masyarakat tetap terlindungi dari wabah Covid 19, dan masyarakat harus mematuhi protokol kesehatan saat melakukan kegiatan sosial. Artinya, menuntut masyarakat untuk mengubah pola interaksi sebelumnya dalam kehidupan sosial. Hasil penelitiannya menunjukkan bahwa perubahan tatanan kenormalan baru terdiri dari lingkungan individu, lingkungan keluarga, lingkungan keluarga, lingkungan kerja, lingkungan pemenuhan kebutuhan dasar, dan hiburan. Dalam konteks lingkungan keluarga, seluruh keluarga perlu menjalankan tatanan kenormalan baru dengan melakukan perilaku hidup bersih dan sehat di rumah dalam rangka kohesi sosial dan penggunaan masker. Tantangan yang muncul terkait dengan isi pedoman, pelaksana, dan kelompok sasaran. (Herdiana \& Nurul, 2020: 300).

Pembelajaran online dinilai tidak terlalu efektif untuk anak usia sekolah, menurut analisis peneliti di majalah Hilna Putria, Luthfi Hamdani Maula, dan Din Azwar Uswatun. Ada beberapa faktor yang membantu guru dalam proses pembelajaran online. Yakni, ketersediaan ponsel, alokasi, dan jaringan internet yang stabil. Selain faktor yang mendukung pembelajaran online, juga terdapat beberapa kendala bagi guru saat pembelajaran online. Inhibitor antara lain karena tidak semua siswa memiliki handphone dan masih banyak orang tua yang sibuk bekerja (Putria et al., 2020: 861).

Menurut hasil wawancara peneliti dengan Kepala SMP Negeri 7 Sijunjung Hal tersebut di atas juga dialami oleh SMP Negeri 7 Sijunjung. Banyaknya tugas yang diberikan oleh guru, seringkali menemukan keluhan dalam proses pembelajaran luring ataupun daring sehingga dapat mengganggu dalam pengelolaan pembelajaran. Beban belajar yang diberikan kepada siswa tentunya harus diperhitungkan secara baik dan terukur, baik dari segi isi materi ataupun waktu yang efektif. Hal yang perlu diperhatikan bahwa, proses pembelajan tidak harus dengan memperbanyak tugas dengan memberikan soal-soal yang terlalu banyak. Pada hakikanya guru harus mencari solusi dengan cara menyampaikan pembelajaran agar lebih menarik dan Memotivasi siswa untuk berpartisipasi dalam proses pembelajaran dengan lebih antusias. Walaupun, proses pembelajaran dilakukan dengan daring ataupun luring, respon seorang guru berbentuk sapaan, reward dan punishment terhadap tugas yang dikerjakan merupakan hal yang tidak boleh untuk dilupakan. Terdapat beberapa asumsi dari siswa yang merasa dirinya diperdayai oleh banyaknya tugas yang diterima, akan tetapi belum ada feedback dari guru, seperti tugas yang berbentuk soal yang telah dikerjakan secara maksimal, akan tetapi guru belum mengoreksi atau menilainya dengan semestinya (Wawancara, Kepala SMP Negeri 7 Sijunjung, 24 Agustus 2020). 
Menurut guru PAI SMP Negeri 7 Sijunjung, pembelajaran mandiri siswa SMP Negeri 7 Sijunjung di rumah belum cukup efektif. Bahkan dengan kemandirian belajar sebesar ini, merupakan syarat yang harus segera dipenuhi dalam proses pembelajaran online. Siswa kurang memahami materi yang diberikan oleh guru. Setelah itu, banyak siswa yang tidak menyelesaikan tugas yang diberikan oleh guru dan tidak mengumpulkannya. Proses kegiatan belajar siswa tidak efektif dan tidak sesederhana yang diharapkan dalam memahami materi dan mengerjakan tugas. Adalah umum bagi siswa untuk salah memahami konten penting. Selain itu, materi yang diberikan dan membutuhkan penjelasan yang lebih rinci dan menyeluruh. Terlebih lagi pada materi yang sangat membutuhkan pemahaman yang harus segera memperoleh penjelasan dari seorang guru. Makanya muncullah problematika, bahwa pembelajaran daring tidak dapat dengan segera mengatasi problematika tersebut. Ditambah lagi dengan pendampingan dari orang tua yang belum maksimal dalam proses pembelajaran daring tersebut. Orangtua dan siswa tidak dapat berperan selayaknya seorang guru sebagai pengampu materi dalam proses pembelajaran. Kebanyakan dari orangtua siswa juga mempunyai keterbatasan dalam memahami isi materi pembelajaran dan kurang mengikuti perkembangan teknologi. Sehingga pada akhirnya problematika banyak muncul akibat dari hal di atas (Wawancara, Guru PAI SMP Negeri 7 Sijunjung, 25 Agustus 2020).

Peneliti menggunakan pendekatan studi kasus dalam penelitian ini. Pendekatan studi kasus yang digunakan peneliti menggunakan metodologi kualitatif. Peneliti sedang menyelidiki masalah terkait manajemen pembelajaran online selama pandemi Covid di SMP Negeri 7 Sijunjung. Yang dimaksud peneliti dalam penelitian ini adalah suatu peristiwa, proses pembelajaran, kegiatan pembelajaran, program pembelajaran, atau dalam hal ini satu orang atau lebih sebagai guru mata pelajaran. Peneliti mengumpulkan informasi status gejala yaitu di situs penelitian manajemen pembelajaran online selama pandemi Covid di SMP Negeri 7 Sijunjung, . Artinya, peneliti tidak bermaksud menguji hipotesis tertentu. The hanya menjelaskan apa variabel tujuan penelitian, gejala, atau situasi.

Dalam penelitian kualitatif ini, alat atau sarana utama pengumpulan data adalah peneliti sendiri dengan cara mengamati, menanya, mendengarkan, menanya, dan mengambil data penelitian. Peneliti juga menerima data yang valid, jadi semua responden. Instrumen yang peneliti gunakan untuk mengumpulkan data dengan metode observasi adalah kamera digital, tabel, schedule, catatan lapangan dan alat-alat pendukung lainnya. Instrument yang peneliti gunakan dalam metode wawancara adalah daftar pertanyaan wawancara dan alat perekam. Instrumen yang peneliti gunakan dengan metode studi dokumentasi adalah dokumentasi profil sekolah, dokumentasi gambar kegiatan, dokumentasi video kegiatan dan alat-alat pendukung lainnya yang berkenaan dengan implementasi Manajemen pembelajaran online di masa pandemi Covid-19 di SMP Negeri 7 Sijunjung.

Sumber data dalam penelitian ini peneliti pilih tidak berdasarkan kedekatan emosional, partner, dan lain-lainnya yang dapat mempengaruhi objektivitas dari perolehan data, akan tetapi data yang diperoleh murni karena sesuai dengan kepentingan permasalahan dan tujuasn penelitian. Seluruh informan dalam penelitian ini adalah mereka yang peneliti pilih yang sesuai dengan kepentingan permasalahan dan tujuan penelitian. 
Sumber data utama dalam penelitian ini adalah kepala sekolah, wakil kepala sekolah, dan guru mata pelajaran SMP Negeri 7 Sijunjung di Kabupaten Sijunjung. Sumber data sekunder berupa dokumen tentang masalah penelitian seperti SMP Negeri 7 Sijunjung.

Metode pengumpulan data dalam penelitian ini menggunakan observasi, wawancara mendalam, dan survei terdokumentasi. Dalam penelitian ini, peneliti juga menggunakan teknik triangulasi data. Dalam triangulasi, peneliti menggabungkan beberapa perspektif yang sering digunakan untuk menyempurnakan data. Triangulasi metode dalam penelitian ini adalah peneliti menggunakan metode validasi data yang berbeda dengan data yang digunakan untuk mengecek atau membandingkan dua tanggal. Tujuan dari triangulasi ini adalah untuk membandingkan data dari sumber data yang berbeda dan menggunakan metode yang berbeda untuk menentukan tingkat keaslian data. Dengan triangulasi ini, peneliti percaya bahwa keandalan data lebih dapat diandalkan. Teknik triangulasi dalam penelitian ini terdiri dari triangulasi metode dan sumber. Triangulasi peneliti data memungkinkan informasi diperoleh dari berbagai sumber data. Data yang sama diambil atau dikumpulkan dari sumbernya.

Teknik analisis data dalam penelitian ini, peneliti mengambil salah satu modelnya dari Model Miles dan Huberman, yaitu analisis data kualitatif dilakukan secara interaktif dan berlangsung secara terus-menerus dari mulai pengempulan data di lapangan sampai selesai, tuntas dan jenuh. Langkah-langkanya adalah sebagai berikut, yaitu: Reduksi data, Penyajian data dan Penarikan kesimpulan dan Verifikasi (Miles \& Huberman, 1984: 133).

\section{Hasil dan Pembahasan}

SMP Negeri 7 Sijunjung telah melaksanakan perencanaan dalam pembelajaran secara daring. Perencanaan tersebut dilaksanakan dengan mengadakan rapat bersama para wali murid dan pihak sekolah. Para peserta rapat dari wali murid diwakili oleh beberapa orang saja yang tergabung ke dalam komite sekolah. Hasil rapat diumumkan kepada seluruh wali murid. Sekolah mengeluarkan surat izin ata surat pemberiatahuan tentang proses pembelajaran selama masa wabah covid 19. Proses perencanaan dalam pembelajaran daring dapat terlaksana dengan baik. Hal tersebut dapat terwujudkan karena kerjasama dengan berbagai pihak dapat terbangun dengan baik. Para guru yang mengajar juga mengacu kepada perencanaan yang ditetapkan oleh pihak SMP Negeri 7 Sijunjung.

Hal ini sejalan dengan jurnal penelitian yang dikelola oleh Muhammad Kasim Maskia yang menyebutkan bahwa ada dua poin penting yang harus diperhatikan pendidik dalam merencanakan pembelajaran. Pertama, bersiaplah untuk merencanakan kegiatan belajar Anda. Kegiatan ini meliputi mengidentifikasi kondisi yang melingkupi siswa, memahami karakteristik siswa, dan memahami gaya dan kemampuan belajar siswa. Dan saya memiliki keterampilan sebagai pendidik profesional. Kedua, kegiatan perencanaan pembelajaran meliputi pengembangan kurikulum dan pengembangan perencanaan pelaksanaan pembelajaran (RPP). Dampak kegiatan perencanaan pembelajaran terhadap kegiatan pembelajaran berkorelasi dengan kegiatan bagaimana pendidik mengajar dan bagaimana siswa belajar. Kegiatan pendidikan ini merupakan kegiatan yang disadari dan direncanakan. Suatu kegiatan yang direncanakan atau kegiatan yang memiliki tiga elemen kunci: perencanaan, pelaksanaan, dan evaluasi. Ajarkan dengan cara yang sama. Semua pendidik perlu mempersiapkan pelajaran sebelum memulai proses pembelajaran. Pendidik dengan kurikulum kegiatan pembelajaran dapat mencapai hasil yang maksimal dengan menciptakan 
tujuan kehidupan berbangsa dan bernegara, yaitu mencerdaskan kehidupan bangsa.(Maskiah, 2016: 484).

Sebuah perencanaan merupakan suatu tahapan proses dalam menetapkan serta memanfaatkan SDM secara terintegrasi, yang dinginkan mampu untuk menunjang semua kegiatan dan mengupayakan agar tercapainya sebuah tujuan dengan efektif dan efesien. Dalam hal proses pembelajaran, perencanaan dapat dimaknai sebagai upaya untuk menyusun materi-materi pembelajaran, pemanfaatan media dalam pembelajaran, pemanfaatan sebuah pendekatan atau metode dalam peroses pembelajaran dan pengevaluasian dalam penilaian pada suatu alokasi waktu yang akan dilaksanakan untuk masa yang telah ditetapkan agar terwujudnya hal yang dinginkan dengan menentukan perencanaan proses pembelajaran dengan menggunakan kurikulum, rencana pelaksanaan pembelajaran yang paling sedikit meliputi evaluasi tujuan pembelajaran, bahan ajar, metode pembelajaran, sumber belajar, dan hasil belajar (Aqib, 2013: 45).

Pelaksanan pembelajaran secara daring di SMP Negeri 7 Sijunjung yaitu dengan cara menerapkan sistem yang terbaru, yang mana sistem tersebut belum pernah diterapkan sebelumnya. Sistemnya adalah para guru memamfaatkan aplikasi grup Whats $A p p$ dan Google classroom. Pembelajaran terlaksana melalui aplikasi tersebut. Setiap guru memberikan materi pembelajaran melalui aplikasi WhatsApp dan Google classroom. Setiap hari para guru mengontrol jalannya pembelajarannya melalui aplikasi tersebut. Para siswa mengirimkan tugasnya juga melalui aplikasi Whats $A p p$ dan Google classroom. Semua gambar, video dan teks juga dikirimkan melalui aplikasi tersebut. Jadi, guru hanya membuka link aplikasi Whats $A p p$ dan Google classroom untuk mengoreksi segala macam tugas yang dikirimkan oleh para murid.

Ini adalah implementasi pembelajaran online di Pandemi Covid19 di jurusan teknik elektro, SPADA UNTIRTA, Vclass, google meet, zoom, whatsapp, telegram, google classroom, youtube, facebook, dan Messenger. Implementasi online Pembelajaran berjalan lancar, tetapi menganggap kurang efektif. Hasil belajar siswa bervariasi, mulai dari kurang, sedang hingga baik. Batas Siswa dan Instruktur Online Belajar 4444 Lainnya Meliputi: Tugas Internet, Jaringan Tidak Stabil, dan Tersedianya Alat Pendukung seperti Gadget dan Laptop. Pembelajaran online diyakini lebih efektif diterapkan di masa pandemi COVID-19, namun diperlukan model yang lebih beragam agar tetap menarik dalam jangka panjang. Hampir semua instruktur kursus pelatihan kejuruan teknik elektro menggunakan Google Meet untuk mengaktifkan pembelajaran online (Irwanto, 2020: 28).

Pelaksanaan pembelajaran merupakan proses pembelajaran di kelas yang menjadi inti dari kegiatan sekolah. Oleh karena itu, pelaksanaan pendidikan adalah interaksi antara guru dan siswa dalam mengkomunikasikan materi kepada siswa dan mencapai tujuan pendidikan tersebut. Fitur implementasi ini mencakup berbagai kegiatan manajemen dan kepemimpinan. Pembelajaran guru dan manajemen siswa di kelas. Selain itu, mencakup berbagai kegiatan organisasi manajemen sekolah, seperti pembagian kerja ke dalam berbagai tugas khusus yang harus dilakukan guru dan berbagai fungsi administrasi lainnya. Oleh karena itu, ada dua hal yang terlibat dalam melakukan pembelajaran: manajemen kelas dan siswa dan manajemen guru. (Aqib, 2013: 48-49).

SMP Negeri 7 Sijunjung telah melakukan evaluasi pembelajaran daring yang bertujuan untuk mengukur proses pembelajaran yang selama ini telah berjalan. Walaupu terdapat beberapa kendala. Namun, SMP Negeri 7 Sijunjung berupaya semaksimal mukin agar proses pembelajaran secara daring tetap berjalan dengan sempurna. Kendala yang ditemukan adalah terjadi penurunan Pemahaman siswa terhadap materi yang diberikan oleh guru dan juga 
sulitnya para guru mengontrol tingkah laku siswa ketika pembelajaran itu sedang berlangsung. Disamping itu, ketika proses pembelajaran daring berlangsung terdapat gangguan jaringan iternet yang mengakibatkan para Siswa tidak dapat mengikuti proses pembelajaran secara maksimal. Hal ini sesuai dengan jurnal penelitian yang dipimpin oleh Ifrah Syahmina, Indayana Febriani Tanjung, dan Rohani, dan kendala home learning mata pelajaran biologi adalah jaringan internet, ketiadaan internet siswa, dan kondisi keuangan siswa. Saya mengerti. Kepemilikan perangkat atau laptop. Faktor pendukungnya adalah teknologi, lokasi pembelajaran sesuai Protokol Kesehatan COVID19, sumber belajar, media pembelajaran yang sesuai, rencana pelaksanaan pembelajaran online yang dirancang guru, semangat belajar siswa, dan sarana prasarana yang sesuai. Intinya pelaksanaan home study biologi di Madrasah Aliyah Negeri 1 Medan sudah efektif dilaksanakan sesuai dengan peraturan pemerintah melalui Surat Edaran 15 Tahun 2020. (Syahmina et al., 2020: 320).

Berdasarkan pernyataan di atas, ia menjelaskan bahwa penerapan pembelajaran online terapan tidak terlalu efektif karena AI dan KD tidak dapat dicapai secara optimal. Pembelajaran yang tidak berpedoman pada KI dan KD tidak mengarah pada tujuan pembelajaran oleh KI dan KD. Hal ini juga dilaporkan oleh Menteri Pendidikan Republik Indonesia Nadim Makarim tentang kurangnya tujuan AI dan KD dalam pembelajaran online. Secara umum pembelajaran ada tujuan AI dan KD yang mendukung hasil belajar siswa, namun pandemi Covid19 mengharuskan siswa belajar dari rumah, dan pembelajaran online membebani tujuan AI dan KD. Pembelajaran online berarti guru dan siswa tidak dapat bertemu secara langsung, sehingga tidak dapat mengetahui secara langsung apakah telah memahami materi dengan benar.

\section{Penutup}

Perencanaan pembelajaran di SMP Negeri 7 Sijunjung pada awalnya melalui tahap rapat, dan selanjutnya pihak sekolah membuat surat izin yang nantinya akan disebarkan kepada orangtua/wali murid. Perencanaan pembelajaran di SMP Negeri 7 Sijunjung sudah berjalan dengan baik, hal ini terihat dari pelaksanaannya yang mengikuti prosedur dari surat edaran, ditambah dengan kerjasama beberapa pihak, seperti kerja sama antar kepala sekolah dan guru, ataupun kerjasama antara sesama guru.

Sekolah telah mengembangkan strategi baru untuk menerapkan pembelajaran di SMP Negeri 7 Sijunjung untuk pembelajaran online. Artinya, siapkan grup WhatsApp untuk mengirim tugas kepada siswa. Guru memantau setiap hari dengan mengirimkan link online melalui jaringan internet. Tautan ini akan digunakan oleh siswa nanti untuk mengambil tugas. Dalam pembelajaran online, tugas guru adalah mengirimkan materi berupa foto, video, atau lembar kerja dan mengirimkannya kepada siswa.

Evaluasi pembelajaran online di SMP Negeri 7 Sijunjung diawali dengan monitoring hasil belajar. Dalam hal ini, hasil belajar yang berkaitan dengan materi menjadi berkurang karena materi yang diajarkan tidak sepenuhnya diserap oleh siswa. Selain itu, hasil belajar meningkat dalam hal keterampilan seperti bakat. 


\section{Bibliografi}

Al-Maraghi, Ahmad Musthafa. (1989). Terjemah Tafsir Al-Maraghi. Semarang: Toha Putra, cet I.

Al-Shabuni, Muhammad Ali. (2001). Shafwat al-Tafasir, Jilid IV. Beirut: Dar al-Fikr. 2001.

Aqib, Zainal. (2013). Model-Model, Media, dan Startegi Pembelajaran Kontekstual (Inovatif). Bandung: Yrama Widya.

Buchari, Agustini. (2018). Peran Guru dalam Pengelolaan Pembelajaran, Jurnal Ilmiah Iqra' Vol 12, No 2.

Herdiana, Dian dan Nurul, Supriatna. (2020). Implikasi Tatanan Normal Baru Terbadap Kebidupan Sosial Kemasyarakatan. Jurnal Ilmiah Dinamika Sosial. Vol. 4. No. 2.

Irwanto. (2020). Pelaksanaan Pembelajaran Online (Daring) di Program Studi Pendidikan Vokasional Teknk Elektro Untirta di Masa Pandemi Covid-19. Jurnal dalam Prosiding Seminar Nasional Pendidikan FKIP UNTIRTA. Vol. 3. No. 1.

Maskiah, Muhammad Qasim. (2016). Perencanaan Pengajaran dalam Kegiatan Pembelajaan. Jurnal Diskursus Islam. Vol. 4. No. 3.

Miles, M.B \& Huberman A.M. (1984). Analisis Data Kualitatif. Terjemahan oleh Tjetjep Rohendi Rohidi. 1992. Jakarta: Penerbit Universitas Indonesia.

Putria, Hilna, Dkk. (2020). Analisis Proses Pembelajaran dalam Jaringan (DARING) Masa Pandemi Covid- 19 Pada Guru Sekolah Dasar. Jurnal Basicedu. Vol. 4. No. 4.

Qomar, Mujamil. (2007). Manajemen Pendidikan Islam. Surabaya: Penerbit Erlangga.

Syahmina, Ifrah. Dkk. (2020). Efektivitas Pembelajaran Biologi pada Masa Pandemi Covid-19 di Madrasah Negeri Medan. Jurnal Biolokus. Vol. 3. No. 2. 